\title{
A Development of the Flipped Learning Model Using the Critical Inquiry Process to Enhance Research Skills
}

\author{
https://doi.org/10.3991/ijim.v15i03.17905 \\ Siriwatchana Kaeophanuek ${ }^{\bowtie}$, Naparat Chookerd \\ Walailak University, Nakhon Si Thammarat, Thailand \\ ksirivajemail.wu.ac.th
}

\begin{abstract}
This research proposes a learning process model of the flipped classroom to develop research skills by applying the critical inquiry theory to instructional design to develop thinking and find answers and research skills, critical competencies for conducting research. Our flipped-classroom model was constructed with three phases, including pre-class, in-class, and after-class. The research methodology was separated into two stages: The main stage incorporates a literature review to establish the learning process model, while the second stage includes an expert's assessment of the learning model's suitability. Experts strongly agree with this learning model. We intend to use our model to help teachers prepare and conduct learning activities to enhance undergraduate students' research skills.
\end{abstract}

Keywords - Flipped classroom, blended learning, critical inquiry, research skill

\section{Introduction}

Research skills are critical and essential for twenty-first-century learning [1]. They concern graduates who need a set of skills to manage various real-life situations, especially critical thinking, creative problem solving, information management, and lifelong learning skills. Developing a research process or concept is difficult for students. Durmuşçelebi [2] revealed that the factors that affect students' interests and confidence when conducting research are the students' academic motivation, research issues, research competency, and an impressive instructional design that encourages student confidence and promotes enjoyment in terms of the topic. Therefore, this is a challenge for teachers. It is not only about teaching students to think about research problems and how to solve them, but also about developing various skills and knowledge.

Traditional learning approaches that focus on the teacher as the center of knowledge have been reduced in importance. Instead, there has been a shift to Web 2.0 technology as it allows students to study everywhere, even outside the classroom [3]. Moreover, students learn to use technology from kindergarten to university. As a result, instructional design has been widely used to integrate various ICT types into teaching [4]. Therefore, in learning in this era, students are expected to work together and independently before entering the classroom, using various technologies. 
As a teaching approach for higher education, the flipped classroom's usefulness has been widely applied $[3,5,6]$. Achievement in a flipped classroom focuses on student comprehension, with hands-on activities rather than listening to lectures [7]. Besides, the flipped classroom encourages students to create a learning community and share ideas to solve issues and increase student interaction [8]. However, using flipped classroom teaching methods may make it challenging to motivate students to study for lessons beforehand, which may differ in each subject. To answer the above questions, we initially investigate how we can develop research skills for undergraduate students by using flipped classroom instruction methods integrated with the critical inquiry concept. Several researchers have published work on implementing inquiry-based instruction features within a flipped classroom instructional context [9-11]. However, there is still no research that deals with applying critical inquiry techniques and flipped classrooms in research skill development for undergraduate students. Consequently, this is an exciting challenge.

In this research, we investigate the suitable learning model with experts for enhancing research skills. The rest of the paper is organized as follows: In section 2, we briefly review the literature on flipped classrooms, the critical inquiry method, and research skills. Sections 4 describes a model and combines the results of the individual stages following research questions. The paper closes with a discussion and conclusions regarding the results. Two research questions include:

- RQ1: How is the flipped classroom integrated with the critical inquiry (FCCI) learning approach to improve students' research skills?

- RQ2: What are experts' opinions on the FCCI learning model to improve student research skills?

\section{$2 \quad$ Literature Review}

\subsection{Flipped classrooms}

The flipped classroom, also known as the 'inverted classroom,' is an educational management concept that enables students to learn and acquire information independently, outside the classroom, through video or other media prepared by their teachers. When students come to the classroom, teachers review their knowledge and understanding of the exercise or practice [12]. The most crucial thing regarding using this method is the combination of traditional learning approaches with an information-based teaching model that uses comprehensive information technology and online teaching resources, including pre-prepared teaching videos and external resources on various platforms for the student, which they can access by themselves. The instructor serves as a facilitator to promote and provide guidance [13]. Consequently, the flipped classroom approach has been widely used in recent years because it can empower students to generate information based on their own experience, creating meaningful learning. 


\subsection{Critical inquiry learning}

Critical inquiry is a concept that was founded with the integration of the inquirybased learning method and critical theory [14]. This term 'critical inquiry' was first mentioned by Sirotnik [15]. This includes using personal thinking, debate, decision making, practice and assessment, scientific evidence-based analysis, interpretation, and review [16]. Critical inquiry techniques help develop reasoning ability and logical thinking in question-asking skills to encourage students to develop a strategic thinking process for their question-formulating processes [17]. These involve thinking about the information and thinking about thinking, such as 'Is this idea correct?', supporting reasons, 'how to get this idea,' and question types. These encourage students to think about and review a situation until they realize the results of their actions. They see that there are guidelines for using critical inquiry to help them and allow them to practice finding factors or sources of information about problems that have already occurred. It also develops students' critical thinking skills and allows them to practice understanding various contexts and related environments.

In this research, we revised critical inquiry techniques, mainly based on Kaeophanuek et al.'s [18] research, and synthesized other research to design an appropriate technique for flipped classroom teaching research methods skill development. We did this by adding a presentation step to present what they had been researching in various ways [19-23]. The six steps are as follows:

1. Question Posting: The process of encouraging thinking, questioning, related problem identification, and finding an approach to obtain solutions. Students may link this with past learning experiences in order to try to understand a situation and related contexts. The questions should apply to daily life or challenge the ability and curiosity of the students. This keeps them interested and focusing on what is being studied, making assumptions, defining potential solutions, observing, gathering data, preparing for exploration and implementation, summarising the references, and providing evidence for a conclusion.

2. Data Collection: This is the exploration, observation, and investigation of facts obtained from various sources. Many possible solutions are depending on the student's experience and learning process.

3. Analysis: This involves summarising, thinking, analyzing, and categorizing the data collected. Then, there is a need to interpret the information and synthesize the knowledge obtained; this may or may not be supported by the assumptions. Students share what they have learned, strengthening, and developing their knowledge of the concepts involved and increasing their collaboration skills.

4. Discussion: This is the process that lets the students confirm their findings and proceed to deepen their discovered knowledge. The students link this knowledge with their previous knowledge or deepen it in order to find an explanation for other related situations. They can work with observations to create knowledge when they collaborate with others.

5. Presentation: This is the process that lets the students summarise the knowledge discovered in the previous steps and organize and present their concepts in various ways to communicate with an audience and further develop their understanding. 
6. Reflection: This is the process of reviewing the learning process to recognize and practice thinking, analyzing, and developing their learning process. Students understand and learn from experience and learn to improve themselves continually. Receiving feedback enables them to engage in self-assessment concerning various learning processes they have been involved in, leading to applying their knowledge in other subjects and solving problems creatively.

\subsection{Research skills}

Research skills focus on a set of abilities related to conducting research, from the strategies and instruments needed to the resources required and the interpretation of information value. Therefore, if students possess these abilities, it is easier for them to apply their knowledge to everyday life and other subjects [24]. Our measurement of research skills was adopted from Willison \& O'Regan [25].

The purpose of the research described in this paper is to develop the learning process model, in terms of the flipped classroom method, by applying thinking process development and research techniques and strategies from the critical inquiry concept to construct learning activities to develop the research skills of undergraduate students.

\section{$3 \quad$ Methodology}

The research method has been split into the following phases.

Phase 1: This step was taken in order to design the flipped-classroom learning process through critical inquiry to develop research skills, as follows:

1. Collect and synthesize documents related to the flipped classroom [26-29].

2. Complete a literature review regarding the critical inquiry method published by Kaeophanuek et al. [18,19-23] and apply the instructional design's learning activities.

3. Develop the new learning process, titled the flipped classroom integrated with critical inquiry (FCCI), to enhance student research skills.

Phase 2: The methods for determining the suitability of the critical inquiry learning process through the flipped classroom were as follows:

1. At this stage, the sample group consisted of seven experts holding doctoral degrees, employed as university lecturers, and with relevant experience of at least ten years. These experts consisted of three in research skills and four in educational technology, instructional design, flipped classrooms, and inquiry-based learning.

2. The instruments used in this phase were the in-depth interview and suitability assessment form. The instruments were verified content validity by three experts through the index of items objective congruence (IOC). The results indicate that all items can be used because they have a correct index between 0.66 and 1.00. It was found that the suitability of IOC was at 0.83 .

3. Analyze the outcomes of assessing the suitability of the FCCI-based learning process to develop research skills by using the mean $(\bar{x})$ and standard deviation (S.D.) indicators related to the five-point Likert scale used to determine the suitability of the activity. 


\section{$4 \quad$ Results}

To address two research questions, the findings of this study are as follows:

- RQ1: How is the FCCI learning approach used to improve the research skills of students?

- RQ2: What are the experts' opinions on the FCCI learning model to improve student research skills?

\subsection{Steps to develop research skills in the FCCI learning model}

Preliminary findings: The researcher reviewed flipped classroom literature to synthesize and design learning processes using a critical inquiry technique for research skill advancement. The learning procedures were divided into three phases, adopting from the model previously proposed by Estes et al. [29], according to Figure 1, as follows:

Phase 1 - Pre-Class: The content delivery step, which consisted of the following steps:

1. Students explored content by themselves. This phase was performed at home before the in-class session. Students were supposed to watch educational video clips or other media. The duration of the videos on each topic was no more than 20 minutes.

2. Students made short notes individually about the teacher's topics by using an online learning platform such as Moodle, which the teacher created to facilitate learning. On this platform, students watch video lectures and complete the pre-class assignments. The teacher updates the students' assignments and verifies their progress on the Moodle platform's learning tasks in real-time. There are channels for communication through Moodle, such as chat rooms and discussion boards, by which students interact and address issues with each other to fix any problems or ask the instructor questions.

3. Students must answer questions about what they learned before attending the class This learning was preparation for knowledge on and understanding various content needed to undertake various activities in the classroom. Examples of self-reflection (R) questions include:

a) What do I know about this topic or subject?

b) What would I like to learn about this topic or subject?

c) How will I prepare to learn this topic for use in the coming class?

d) What kinds of research do I need to do?

e) What are my goals for this assignment?

f) Have I given myself ample time to think about this assignment, and have I brainstormed possible solutions? 


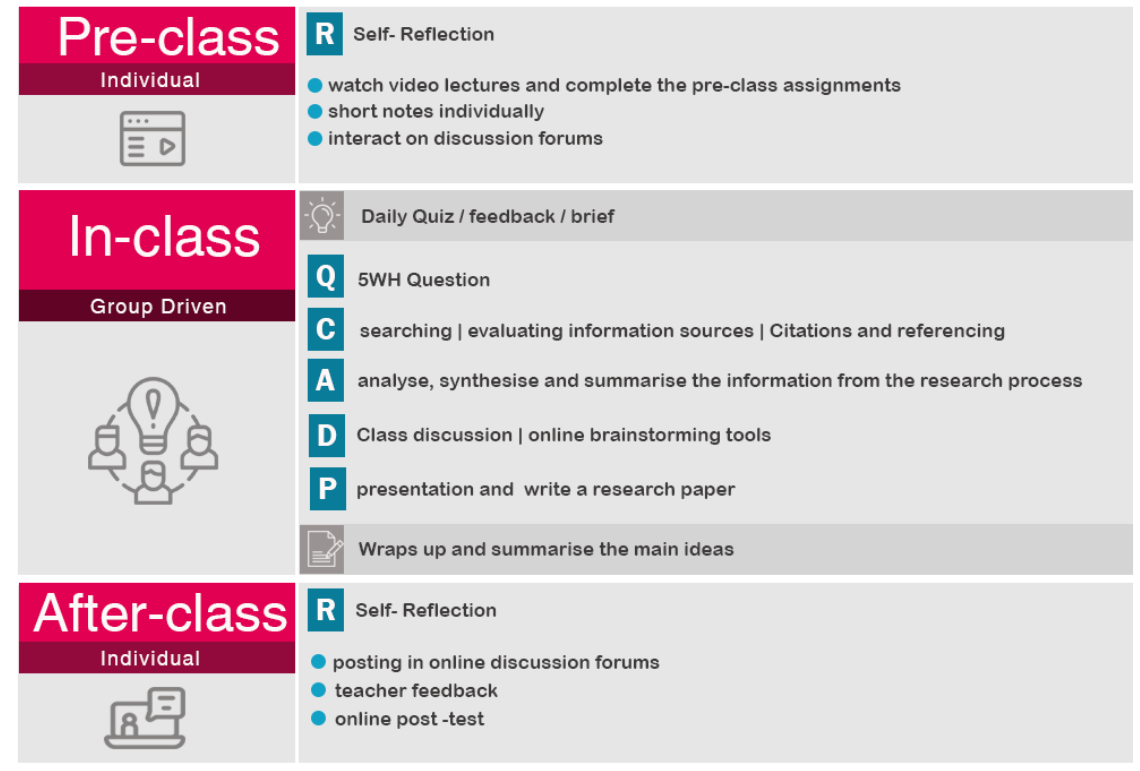

Fig. 1. Steps in flipped classroom integrated with critical inquiry (FCCI)

Phase 2 - In-Class: The in-class session involves practical exercises that mainly consist of group activities. Such activities increase peer interaction and allow the students to focus intensely on higher cognitive and group-based learning by taking part in small group discussions. The advantage of this activity is that it allows students to improve their critical thinking and problem-solving skills and enhance their interpersonal skills through the learning process. The learning activity is divided into three sections.

1. Introduction: The in-class section usually begins with the pre-class step, in which students are encouraged to review learning materials before classroom attendance. Specifically, the teacher assigns the quiz through Moodle. This quiz's main point is to assess students' comprehension of the content they learned about in the video lecture before the class. The teacher must have access to the students' evaluation scores immediately to check the correctness of the individual student's understanding and be aware of the need to explain in detail if a student has misunderstood or does not understand something. However, flipped classrooms possess some fundamental limitations, e.g., an immediate response cannot be provided to students when they have concerns about pre-class materials. Therefore, this step focuses on students' questions that have arisen due to the pre-class material review. The teacher focuses on answering students' questions through the Moodle system or elaborating on them in the classroom in the first 15 minutes. This clears any doubts on the students' part and opens their minds to learning through other activities, helping them better understand.

2. Activities and practice: We utilized the critical inquiry technique for designing learning activities. Consequently, students have the opportunity to work in peer 
groups or as a team. Teamwork allows them to learn from listening to each other's questions and points of view. The learning activities are as follows:

Q: Question posting: Questioning is an activity that involves asking questions about a research problem. There are research samples for each group to think about, analyze, and ask questions about using the $5 \mathrm{Ws} \& \mathrm{H}$ concept. These are as follows:

- What: What is the research problem? What has happened to this research? What was conducted to complete the research, what was involved processes, what methods were used, and the results and conclusion?

- Who: Who conducted this research?

- When: When did the research start, and when did it finish? When will we collect the data?

- Where: Where did this research take place?

- Why: Why did this research happen? Why was there a need for it?

- How: How will this research be beneficial?

C: Data collection: This activity trains students to search for information from various sources, relying on knowledge after evaluating a source's credibility.

A: Analysis: This is an activity that allows students to summarise the information obtained from the research process, to collect, think, interpret, and distinguish knowledge gathered in the study process, and present it in various ways that are easy to understand.

D: Discussion: This exercise helps students connect with the information acquired from the exploration stage in more depth, discussed through information presentation. To support the study's evidence, students must explain and offer academic reasons, e.g., using open-ended questions via Padlet, to consider multiple perspectives.

P: Presentation: In this stage, the teacher lets students observe the writing results and discussions from research samples; then, students brainstorm using Stormboard, which helps to brainstorm group members' ideas. The teacher is responsible for summarizing the issues and providing suggestions. Each group then writes and presents the knowledge gained in both poster and research journal formats.

3. Summarise: The process of summarising each session learned through the various activities carried out in the classroom is connected with the information that students have acquired outside the classroom through online platforms. The key to the flipped classroom is time management due to the variety of activities and practices. Teachers are also unable to handle time and lack the content summary process. However, this is considered an essential step in summarising the main ideas of each learning session.

Phase 3 - After Class: The purpose of this process is to provide opportunities for students to integrate what they have learned, including practice and quizzes. Moreover, 
on the Moodle platform, the teacher should allow students to share their learning experience and help each other absorb the new knowledge by generating questions. The critical activity of this phase is the reflection $(\mathbf{R})$. The teacher creates the questions, and students answer them in order to construct knowledge by themselves. Examples of such questions include:

1. What have you learned?

2. How is today's learning connected to previous learning?

3. How can the knowledge learned today be used in the future?

Furthermore, the activities encourage students to collaborate and participate in their projects. The teacher should create a forum for them to ask questions after the learning process has been completed. Teachers need to answer questions because it enables them to continue studying.

\subsection{Suitability of the learning activities of the flipped classroom combined with critical inquiry (The FCCI model)}

The second research question is related to the experts' opinions on the FCCI process to enhance research skills. As assessed and approved by seven experts, the findings of the suitability of the FCCI are as follows (Table 1).

Most of the experts were interested in combining the flipped classroom teaching method with the critical inquiry technique to develop research skills as a practical teaching method. They believed that this method could encourage student learning. The information shown in Table 1 indicates that, overall, experts fully agree that the learning process model associated with the flipped classroom, integrated with critical inquiry, enhances students' research skills. Overall suitability was valued at a high level $(\bar{x}=$ 4.57). However, some experts had suggestions on various issues, as indicated below:

Exp. 3: 'It is a fascinating learning model that could be useful. However, be careful about the quality of the video content for the students to study beforehand, in terms of content presentation, picture and sounds, video duration, and using exciting presentation techniques.'

Exp. 4: 'The activities presented are interesting and can encourage students to enhance their thinking skills and develop these into research skills. However, the researcher should add more reinforcing activities to motivate the students to study the content before entering the class. This will enable the implementation of activities in the classroom to achieve the goal.'

Exp. 7: 'peer-assessment should be included in the evaluation design. The goal is to encourage student ownership and responsibility for learning. Also, there should be progress reports in order to test students' understanding and experience continuously.'

\section{Discussion}

Based on the literature review and the experts' evaluation results, the learning model for developing research skills using flipped classroom teaching methods as a classroom 
management method both online and offline, with the application of the CI technique as a learning strategy for designing activities, will motivate students' mindsets and enhance their practice concerning developing the research skills of undergraduate university students.

Table 1. The results of evaluating FCCI learning to enhance research skills

\begin{tabular}{|l|c|c|l|}
\hline \multicolumn{1}{|c|}{ The learning process model } & $\overline{\boldsymbol{x}}$ & S.D. & $\begin{array}{c}\text { Level of } \\
\text { agreement }\end{array}$ \\
\hline $\begin{array}{l}\text { A learning process model is more interesting than using traditional learning } \\
\text { methods }\end{array}$ & 4.57 & 0.53 & Strongly agree \\
\hline A learning process model can encourage student learning & 4.43 & 0.79 & Agree \\
\hline A learning process model can increase student motivation & 4.29 & 0.76 & Agree \\
\hline A learning process model can provide a good learning experience & 4.29 & 0.76 & Agree \\
\hline A learning process model allows self-paced learning & 4.57 & 0.53 & Strongly agree \\
\hline The critical inquiry techniques achieve the learning outcomes of the course & 4.86 & 0.38 & Strongly agree \\
\hline Using this model enhances learning effectiveness & 4.86 & 0.38 & Strongly agree \\
\hline Using this model improves research skills & 4.71 & 0.49 & Strongly agree \\
\hline Total mean & 4.57 & 0.58 & Strongly agree \\
\hline
\end{tabular}

This model's strengths are that it is the integration of the F.C. teaching method with the CI technique. This allows students to acquire knowledge and understanding and develop thinking processes in various stages. This is suitable for developing research skills; in turn, students learn about research issues and be aware of using different research methods and activities to find answers. The results of this study divided the learning process into three main phases as follows:

1. Pre-class stage: This stage starts by clearly specifying each content's learning outcome in terms of what the teacher wants the students to learn and focuses on preparing video lectures and other media forms following the study. It also shows that students learn better when acquiring data from more than one source [30,31]. The teacher then uploads the prepared materials onto Moodle, the learning management system for creating an online learning environment [32]. Videos should be 15-20 minutes in length [33-37]. It is necessary to recognize the video's quality, which should help students understand the content and grasp the right concept. Such a video does not necessarily use the highest technology because not all teachers have the expertise needed to make videos. Consequently, the teacher should not hesitate to use other people's videos instead [38]. However, teachers may be reluctant to use videos produced by others because they believe that students strongly prefer teachers to make videos of themselves [39,40]. Therefore, details such as the film's duration, the number of clips, or even the learning guidance, are useful information for preclass learning [10,30,41].

2. In-class stage: Compared to traditional learning, students' workload and self-motivation in the flipped classroom are higher because they need to prepare for and actively participate in the class [35]. Therefore, the teacher's role in the flipped classroom also tends to focus on class activities. In this sense, it is crucial and even es- 
sential that time management is based on the class's learning objectives [42]. Research indicates that both internal and external incentives, such as ratings or rewards, to motivate students to participate should be designed to make students feel comfortable, minimize their resistance, change their mindset, and motivate them to accept the flipped classroom [43].

Many researchers state that students frequently compare the flipped classroom with traditional teaching methods $[8,10,44]$. In traditional learning, students are passive, compared with the flipped classroom scenario in which they need to participate actively. However, some students doubt that the new approach is more useful and do not accept it [26]. Consequently, with the new approach of implementing a learning strategy that integrates CI into classroom practices, it would be easier to carry out various activities to create meaningful learning. By having consistent content for both pre-class and in-class situations, students can connect knowledge and be part of a learning process that can develop research skills.

Learning activities using critical inquiry begin with thinking practice by asking students to ask questions. This leads to the identification of research problems related to the development of a project. This may include considerations of the essence of questioning for students to practice logical procedures and to use logic to support the ideas, such as open-ended questions. It also allows them to argue for academic reasons by engaging in good questioning. Guiding questions help students review learning material, promote critical thinking, and positively affect learning performance [45]. Using knowledgeable sources, students can assess the research approach's reliability and use data to analyze the situations logically. This is a primary method for finding credible answers for the research process, including discussions on subjects that have already been studied. Besides, the group activity described in our model has the potential to enhance student teamwork. The usefulness of group activity in flipped classrooms was previously reported by Tague \& Czocher [46].

3. After-class stage: This phase aims to enhance learning outcomes and obtain teacher feedback. Teachers encourage continuous learning by posting points to think about or to have students reflect on their thoughts by asking questions about their learning experience. In addition to engaging in self-learning, classmates can also learn more about other topics by sharing thoughts on the discussion board. An essential aim of reflective learning is to examine student practice more closely to strengthen understanding and gain the skills needed to help achieve more effective classroom practice in the future [47-50].

\section{Conclusion}

To conclude, we proposed developing a learning process model to improve research skills through a flipped classroom and to use a critical inquiry approach to establish the research thinking process. Three stages are included in this model: pre-class, in-class, 
and after-class. We used six critical inquiry thinking processes, including question posting, data collection, analysis, debate, presentation, and reflection, incorporated into each stage to achieve flip learning. Besides, we used online learning tools to empower students with various critical inquiry strategies, such as an online discussion board, online brainstorming tools, online notetaking, reflective journals, and Google documents. This study shows that the evaluation carried out by experts in the field ensures its suitability in developing research skills as an efficient teaching model. We plan to explore this model shortly with undergraduate students in Thailand. Further research needs to be done to investigate how to inspire undergraduates when it comes to research activities [49]. It may also be worth considering the different factors associated with student learning styles and how they influence the flipped classroom's acceptance.

\section{$7 \quad$ Acknowledgement}

This research was supported by grant WU61318 from Walailak University. We are thankful to the School of Informatics and the Institute of Research and Innovation, Walailak University, which significantly supports this research.

\section{$8 \quad$ References}

[1] Sari, D. P, Wulan, A. R. \& Solihat, R. (2019). Developing 21st-century student research skills through assessment matrix and edmodo in biology project. Journal of Physics Conference Series, 1157, (2):1-6, https://doi.org/10.1088/1742-6596/1157/2/022093

[2] Durmuşçelebi, M. (2018). Examination of Students' Academic Motivation, Research Concerns and Research Competency Levels during the Education Period. Universal Journal of Educational Research, 6(10): 2115-2124. https://doi.org/10.13189/ujer.2018.061008

[3] Papadakis, S. (2018). Evaluating pre-service teachers' acceptance of mobile devices with regards to their age and gender: a case study in Greece. International Journal of Mobile Learning and Organisation, 12(4): 336-352. https://doi.org/10.1504/ijmlo.2018.10013372

[4] Papadakis, S., \& Kalogiannakis, M. (2019). Evaluating a course for teaching introductory programming with Scratch to pre-service kindergarten teachers. International Journal of Technology Enhanced Learning, 11(3), 231-246. https://doi.org/10.1504/ijtel.2019.10020 $\underline{447}$

[5] Ozan, O., Yamamoto, G. T. and Demiray, U. (2015) 'Mobile learning technologies and educational applications', Forma Mente, 3(4): 97-109.

[6] Brown, Becki A. (2016). Understanding the Flipped Classroom: Types, Uses and Reactions to a Modern and Evolving Pedagogy. Culminating Projects in Teacher Development. 12. https://repository.stcloudstate.edu/ed_etds/12

[7] Huang, C. K., \& Lin, C. Y. (2017). Flipping Business Education: Transformative Use of Team-Based Learning in Human Resource Management Classrooms. Educational Technology \& Society, 20 (1): 323-336.

[8] Kim, M. K., Kim, S. M., Khera, O., \& Getman, J. (2014). The experience of three flipped classrooms in an urban university: an exploration of design principles. Internet \& Higher Education, 22: 37-50. https://doi.org/10.1016/j.iheduc.2014.04.003

[9] Love, B, Hodge, A., Corritore, C. \& Ernst, Dana C. (2015). Inquiry-Based Learning and the Flipped Classroom Model. PRIMUS, 25:8: 745-762, https://doi.org/10.1080/10511970. $\underline{2015.1046005}$ 
[10] Chen, H.-L., \& Chang, C.-Y. (2017). Integrating the SOP2 Model into the Flipped Classroom to Foster Cognitive Presence and Learning Achievements. Educational Technology \& Society, 20 (1): 274-291.

[11] Çakıroğlu, Ü., \& Öztürk, M. (2017). Flipped Classroom with Problem Based Activities: Exploring Self-regulated Learning in a Programming Language Course. Educational Technology \& Society, 20(1): 337-349.

[12] Zainuddin, Z. \& Halili, S. H. (2016). Flipped Classroom Research and Trends from Different Fields of Study. International Review of Research in Open and Distributed Learning, 17 (3): 313-340. https://doi.org/10.19173/irrodl.v17i3.2274

[13] Bergmann, J., \& Sams, A. (2012). Flip your classroom: Reach every student in every class every day. Washington, DC: Internal Society for Technology in Education. https://doi.org/ $\underline{10.1177 / 073989131401100120}$

[14] McLaren, P. (1989). Life in Schools: An introduction to critical pedagogy in the foundations of education. New York: Longman.

[15] Sirotnik, K. A., \& Oakes, J. (1986). Critical inquiry for school renewal: Liberating theory and practice In Sirotnik, K. A., \& Oakes, J. (Eds.), Critical perspectives on the organization and improvement of schooling (pp. 3-93). Dordrecht: Springer Netherlands. https://doi. org/10.1007/978-94-009-4229-5_1

[16] Foote, S. M., et al. (2012). Exploratory learning through critical inquiry: Survey of Critical Inquiry Programs at Mid-Sized U.S. Universities. IADIS International Conference on Cognition and Exploratory Learning in Digital Age (CELDA 2012), International Association for Development of the Information Society, 155-162.

[17] Perkins, David N. (1986). Thinking Frames. Educational Leadership, 43(8): 4-10.

[18] Kaeophanuek, S., Na-Songkhla, J., \& Nilsook, P. (2019). A Learning Process Model to Enhance Digital Literacy using Critical Inquiry through Digital Storytelling (CIDST). International Journal of Emerging Technologies in Learning (iJET), 14(3): 22-37. https://doi. org/10.3991/ijet.v14i03.8326

[19] Geahigan, G. (1998). Critical Inquiry: Understanding the concept and applying it in the classroom. Art Education, 51(5):10-16. https://doi.org/10.2307/3193716.

[20] Ngeow, K. \& Kong, Y.S. (2003). Learning through discussion: designing tasks for critical inquiry and reflective learning. ERIC clearinghouse on reading English and communication bloomington in.

[21] Lassonde, C. A. (2009). Transforming philosophy and pedagogy through critical inquiry. New England Reading Association Journal, 44(2):41-50.

[22] Gilbert, R. (2014). Planning for student learning. In R. Gilbert \& B. Hoepper, B. (Eds.), Teaching humanities and social sciences: History, geography, economics \& citizenship, (5th ed.) (pp. 66-95). South Melbourne: Cengage Learning Australia.

[23] Bermudez, A. (2015). Four tools for critical inquiry in history, social studies, and civic education. Revista de Estudios Sociales, (52): 102-118. https://doi.org/10.7440/res52.2015. $\underline{07}$

[24] Sari, D. P., Wulan, A. R. \& Solihat, R. (2019). Developing 21st century student research skills through assessment matrix and edmodo in biology project. Journal of Physics Conference Series, 1157(2): 1-5. https://doi.org/10.1088/1742-6596/1157/2/022093

[25] Willison, J. \& O'Regan, K., (2007). Commonly known, commonly not known, totally unknown: a framework for students becoming researchers. Higher Education Research \& Development, 26 (4): 393-409. https://doi.org/10.1080/07294360701658609

[26] Bergmann, J., \& Sams, A. (2014). Flipped learning: Gateway to student engagement. Arlington, VA: International Society for Technology in Education.

[27] Loizou-Raouna, M., \& Lee, K. (2018). A Flipped Classroom Model for Inquiry-Based Learning in Cyprus Primary Education Context. In M. Bajić, N.B. Dohn, M. de Laat, P. Jandrić, T. Ryberg (Eds.), Proceedings of the 11th International Conference on Networked Learning. pp. 210-217. https://doi.org/10.21125/inted.2018.0610 
[28] Lo, C. K. \& Hwang, G. J. (2018). How to advance our understanding of flipped learning: Directions and a descriptive framework for future research. Knowledge Management \& ELearning, 10(4): 441-454. https://doi.org/10.34105/j.kmel.2018.10.027

[29] Estes, M. D., Ingram, R.C\& Liu, J. C. (2014). A review of flipped classroom research, practice, and technologies. International HETL Review, (4). Retrieved from: https://www. hetl.org/feature-articles/a-review-of-flipped-classroomresearch-practice-and-technologies.

[30] Fautch, J. M. (2015). The flipped classroom for teaching organic chemistry in small classes: Is it effective? Chemistry Education: Research and Practice, 16(1): 179-186. https:// doi.org/10.1039/c4rp00230j

[31] Santikarn,B. \& Wichadee, S. (2018). Flipping the Classroom for English Language Learners: A Study of Learning Performance and Perceptions. International Journal of Emerging Technologies in Learning, 13(9): 123-135. https://doi.org/10.3991/ijet.v13i09.7792

[32] Papadakis, S., Kalogiannakis, M., Sifaki, E., \& Vidakis, N. (2018). Evaluating Moodle use via Smart Mobile Phones. A case study in a Greek University. EAI Endorsed Transactions on Creative Technologies, 5(16). https://doi.org/10.4108/eai.10-4-2018.156382

[33] Tattersall, P. (2015). "Flipped" Classroom: Benefits Versus Challenges for Communicative Sciences and Disorders Faculty and Students. Perspectives on Issues in Higher Education. 18. 10.1044/ihe18.1.4. https://doi.org/10.1044/ihe18.1.4

[34] Bhagat, K. K. et al. (2016). The impact of the flipped classroom on mathematics concept learning in high school. Educational Technology \& Society, 19(3): 134-142.

[35] Khanova, J., Roth, M. T., Rodgers, J. E., \& McLaughlin, J. E. (2015). Student experiences across multiple flipped courses in a single curriculum. Medical Education, 49(10): 10381048. https://doi.org/10.1111/medu.12807

[36] Moraros, J. et al. (2015). Flipping for success: evaluating the effectiveness of a novel teaching approach in a graduate level setting. BMC Medical Education, 15: 27. https://doi. org/10.1186/s12909-015-0317-2

[37] Li, J; Zhang, X. \& Hu, Z. (2018). The Design and Application of Flip Classroom Teaching Based on Computer Technology. International Journal of Emerging Technologies in Learning. 13(10): 95-107. https://doi.org/10.3991/ijet.v13i10.9453

[38] Snowden, K. E. (2012). Teacher perceptions of the flipped classroom: using video lectures online to replace traditional in-class lectures. Thesis Prepared for the Degree of Master of Arts. Retrieved from http://digital.library.unt.edu/ark:/67531/metadc149663/m2/1/high res_d/thesis.pdf.

[39] Gouia, R. \& Gunn, C. (2016). Making mathematics meaningful for freshmen students: investigating students' preferences of pre-class videos. Research and Practice in Technology Enhanced Learning. 11(2): 1-8. https://doi.org/10.1186/s41039-015-0026-9

[40] Lam, P., L., Carmen, K. M. \& Chan, C. H. (2019). Strategies to flip a classroom: lessons learnt from a joint-university project. IADIS International Journal on WWW/Internet, 17(1): 51-65.

[41] Wanner, T. \& Palmer, E. (2015). Personalising learning: exploring student and teacher perceptions about flexible learning and assessment in a flipped university course. Computers \& Education, 88: 354-369 https://doi.org/10.1016/j.compedu.2015.07.008

[42] Jdaitawi, Malek M. (2019). The Effect of Flipped Classroom Strategy on Students Learning Outcomes. International Journal of Instruction, 12: 665-680.

[43] Papadakis, S. (2020). Evaluating a game-development approach to teach introductory programming concepts in secondary education. International Journal of Technology Enhanced Learning, 12(2): 127-145. https://doi.org/10.1504/ijtel.2020.106282

[44] Brame, C. (2013). Flipping the classroom. Retrieved [7 Nov. 18] from http://cft.vanderbilt.edu/guides-subpages/flipping-the-classroom/

[45] Thai, Ngoc T., De Wever, B. \& Valcke, M. (2017). The impact of a flipped classroom design on learning performance in higher education: Looking for the best "blend" of lectures and 
guiding questions with feedback. Computers \& Education. https://doi.org/10.1016/j.comp edu.2017.01.003

[46] Tague, J. \& Czocher, J. (2016). A Theoretical Approach to Ensuring Instructional and Curricular Coherence in the Flipped Classroom Model of a Differential Equations Course, Int. J. Res. Undergrad. Math. Educ., 2(2): 223-245. https://doi.org/10.1007/s40753-016-0028-z

[47] Roux, I. le \& Nagel, L. (2018). Seeking the best blend for deep learning in a flipped classroom -viewing student perceptions through the Community of Inquiry lens, Int. J. Educ. Technol. High. Educ., 15(1). https://doi.org/10.1186/s41239-018-0098-x

[48] Solihati, N. \& Mulyono, H. (2017). A Hybrid classroom instruction in second language teacher education (SLTE): A critical reflection of teacher educators', Int. J. Emerg. Technol. Learn., 12(5): 169-180. https://doi.org/10.3991/ijet.v12i05.6989

[49] Papadakis, St., Trampas, A.-M., Barianos, A.-K., Kalogiannakis, M., Vidakis, N.: Evaluating the learning process: the "ThimelEdu" educational game case study. In: Lane, H., Zvacek, S., Uhomoibhi, J. (eds.) Proceedings of the 12th International Conference on Computer Supported Education (CSEDU 2020), 2, pp. 290-298, May 2-4, 2020. https://doi.org/10.5220/0009379902900298

[50] Vidakis, N.; Barianos, A.; Trampas, A.; Papadakis, Stamatios; Kalogiannakis, M. and Vassilakis, K. (2019). Generating Education in-Game Data: The Case of an Ancient Theatre Serious Game. Proceedings of the 11th International Conference on Computer Supported Education - 1, pp. 36-43. https://doi.org/10.5220/0007810800360043

\section{Authors}

Siriwatchana Kaeophanuek received her Ph.D. degree in the Department of Educational Technology and Communication, Faculty of Education, from Chulalongkorn University. She is a lecturer at the School of Informatics, Walailak University, Nakhon Si Thammarat, Thailand. Her current research interests include digital literacy, digital storytelling, instructional design, social media tools for teaching, online engagement, and learning.

Naparat Chookerd currently works as a lecturer at the Digital Content and Media Program, Walailak University, Thailand. She is interested in experimental research about educational Technology, Instruction Design, Online learning, e-Learning; WebBased Instruction, Technology Acceptance Model, Student Engagement, and Digital Media for Learning.

Article submitted 2020-08-20. Resubmitted 2020-12-01. Final acceptance 2020-12-16. Final version published as submitted by the authors. 